\title{
PENGARUH VARIASI PH DENGAN PENAMBAHAN ENZIM BROMELIN ALAMI (Anannas comucus) TERHADAP SIFAT ORGANOLEPTIK KEJU COTTAGE Sylvia Komansilan ${ }^{1}$ Djalal Rosyidi $^{2 *}$ Lilik Eka Radiati $^{3}$ dan Purwadi $^{4}$, Fakultas Peternakan, Universitas Brawijaya \\ Jl. Veteran, Malang-Jawa Timur, 65145 \\ Email : sylviakomansilanmdo@gmail.com
}

\begin{abstract}
Abstrak
Penelitian ini bertujuan untuk menguji pengaruh variasi $\mathrm{pH}$ dengan penambahan enzim bromelin alami buah nanas (Ananas comusus) terhadap sifat organoleptik keju cottage. (Rasa, Aroma, Warna, Aftertaste, dan Overall). Materi dan bahan yang digunakan dalam penelitian ini adalah: Bahan-bahan yang dibutuhkan untuk pembuatan keju Cottage adalah: susu sapi segar sebanyak 28 liter garam dapur1\%, enzim bromelin 3\%. Alat yang digunakan: Tempat/wadah plastik, tempat penampung whey, alat pemanas, thermometer, kain penyaring, pengaduk dan tempat penyimpanan. $\mathrm{pH}$ menggunakan $\mathrm{pH}$ meter. Penelitian ini menggunakan metode percobaan dengan rancangan acak lengkap (RAL) 4 perlakuan dengan Variasi $\mathrm{pH}$ pada saat enzim bromelin ditambahkan adalah K1 $=\mathrm{pH} 4,40 \quad \mathrm{~K} 2=\mathrm{pH} 4.50 \quad \mathrm{~K} 3=\mathrm{pH} 5.40 \quad \mathrm{~K} 4=\mathrm{pH}$ 5.60. Data hasil penelitian akan dianalisis dengan ANOVA jika terdapat perbedaan pengaruh akan dilanjutkan dengan Uji Beda Nyata Terkecil (BNT). Hasil penelitian menunjukkan bahwa terdapat pengaruh yang signifikan $(\mathrm{P}<0.05)$, terhadap warna keju cottage, tetapi tidak memberikan perbedaan yang nyata terhadap, rasa, aroma, aftertaste dan overall tapi dapat diterima oleh panelis.

Kata kunci : Enzim, bromelin, keju, organoleptik.
\end{abstract}

\begin{abstract}
This study aims to examine the effect of $\mathrm{pH}$ variations by adding the natural bromelin pineapple enzyme (Ananas comusus) to the organoleptic properties of cottage cheese. (Taste, Aroma, Color, Aftertaste, and Overall). The Material and Materials used in this research are: the ingredients needed for making cottage cheese are: fres cow milk as 28 liters of kictchen salt 1\%, bromelin enzyme 3\%. Tools usued: plastic containers, heaters, thermometers, filter cloths, stirress and storage areas. $\mathrm{pH}$ use $\mathrm{pH}$ meter. This study used an experimental method with a completely randomized design (RAL) 4 treatment with a variation og pH 4.40, K2 pH 4.50, K3 pH 4.50 K4. 5.60. Data from the research results will be analiysest by ANOVA if there are difference in influence and will be followed by the Smallest Significant Diffrence Test (LSD). The results showed that there was a significant effect $(\mathrm{P}<0.05)$, on the color of cottage cheese, but did not provide a real difference in taste, aroma, aftertaste and overall but was acceptable to the panelists.
\end{abstract}

Keywords : Enzyme, bromelin, cheese, organoleptics.

\section{PENDAHULUAN}

Peningkatan kebutuhan dan konsumsi keju dalam negeri harus diimbangi dengan produksi keju, yang berbahan dasar susu sapi yang di produksi oleh peternak lokal, dengan teknologi dan bahan-bahan yang tersedia secara lokal.

Dalam proses produksinya, keju umumnya menggunakan asam asetat dan enzim renin untuk memperoleh curd yang akhirnya akan diproses lebih lanjut dengan banyak cara tergantung dari keju apa yang akan dihasilkan. Enzim renin sendiri merupakan enzim yang bertugas untuk mencerna protein serta digunakan untuk menggumpalkan susu. Efektif tidaknya curd yang merupakan produk transisi antara susu dengan keju ditentukan oleh kemampuan asam asetat dan enzim renin (Silveira dkk., 2005). 
Keju cottage merupakan salah satu produk keju yang bernilai jual tinggi. Chandan, et al., (2016) menjelaskan bahwa keju cottage merupakan keju lunak dengan kandungan lemak dibawah $4 \%$ dan memiliki kadar air tidak lebih dari $80 \%$ dan proses konsumsinya dengan mencampurkannya ke dalam krim. Hal ini berbeda dengan keju cheddar yang memiliki kandungan lemak 50\% dan kandungan air maksimum 39\% dan cream cheese dengan kandungan lemak 33\% dan kandungan air maksimum 55\%. Keju Cottage merupakan keju yang tidak melewati proses pemeraman dan memiliki kandungan air yang tinggi. Chandan et al.,(2016). Enzim merupakan kelompok protein dimana berfungsi mengatur perubahan kimia dalam tubuh termasuk proses hidrolisis, oksidasi reduksi, adisi, isomerase, pemutusan rantai karbon serta transfer radikal (Sumardjo, 2006). Dengan kata lain, enzim merupakan merupakan protein yang fungsinya sebagai biokatalis. Kelebihan enzim dibandingkan katalis biasa adalah dapat meningkatkan produk beribu kali lebih tinggi, bekerja pada $\mathrm{pH}$ yang relatif netral dan suhu yang relatif rendah, dan bersifat spesifik dan selektif terhadap subtrat tertentu (Chang, 2005).

Dewasa ini enzim yang berasal dari tanaman merupakan alternatif untuk untuk menggantikan penggunaan enzim konvensional. Salah satu enzim yang dimanfaatkan adalah enzim bromelin dari nanas. Enzim bromelin dapat diaplikasikan dalam pembuatan keju. Bromelin terdapat pada semua bagian nanas seperti buah, batang, bonggol, mahkota dan kulit.

Penelitian terkait produksi keju dengan menggunakan protease dari ekstrak buah nanas secara alami masih sangat terbatas, dan dapat menghasikan keju yang lunak, mudah meleleh (hight meltability), mudah mulur (good strecthability) dan membentuk serat-serat saat diregangkan sehingga cocok untuk digunakan dalam pembuatan pizza maupun keju olesan (Kapoor dan Metsger, 2008; McMahon et al,2005). Enzim bromelin merupakan salah satu enzim proteolitik yang digunakan dalam penggumpalan susu. Proses pembuatan keju dipengaruhi oleh $\mathrm{PH}$, suhu dan waktu penambahan ekstrak enzim bromelin serta waktu inkubasi.

Jaya dan Hadikusuma, (2009) menjelaskan bahwa pemanfaatan bonggol nanas dan skim menghasilkan keju cottage dengan kadar protein 10,34\% hingga 12,77\%, kadar air 70,5\% hingga 85,78\%, $\mathrm{pH} 4,358-4,748$, dan rendemen 11,85-15,77. Sementara itu pemanfaatan pada bagian buah belum ada informasi yang tersedia di publik.

Secara umum mutu produk pangan tidak cukup hanya berdasarkan analisis sifat-sifat obyektifnya melainkan juga sifat-sifat inderawinya ,(Nisa T.K.,2013).Oleh karena itu, Keunikan yang diangkat dalam tulisan ini yaitu daya terima masyarakat terhadap keju cottage hasil produksi dari curd yang dihasilkan dengan enzim bromelin yang menggunakan buah nanas. Di Sulawesi Utara khususnya daerah Kotamobagu sebagai penghasil buah nanas terbesar, dengan memanfaatkan potensi buah lokal , diharapkan dapat memberikan sumbangsih yang besar untuk ilmu pengetahuan dan teknologi tepat guna 
Jurnal Sains Peternakan

Vol 7 No 1, Juni 2019, 54-61

ISSN 2579-4450

untuk menghasilkan keju cottage dengan hasil dan komposisi yang optimal yang disukai dan diterima oleh konsumen.

\section{MATERI DAN METODE}

Materi yang digunakan dalam penelitian ini adalah: Enzim bromelin, yang diekstrak dari buah nanas, susu sapi segar yang diambil dari Laboratorium Teknologi Hasil Ternak, Alat yang digunakan: Tempat/wadah plastik, tempat penampung whey, alat pemanas, termometer, kain penyaring, pengaduk dan tempat penyimpanan, $\mathrm{pH}$ meter.

Metode penelitian yang digunakan adalah percobaan Laboratrium dengan rancangan acak lengkap (RAL) 4 perlakuan dan 4 ulangan dengan Variasi pH pada saat enzim bromelin ditambahkan adalah K1 $=\mathrm{pH} 4,40 \quad \mathrm{~K} 2=\mathrm{pH} 4.50 \quad \mathrm{~K} 3=\mathrm{pH} 5.40 \quad \mathrm{~K} 4=\mathrm{pH} 5.60 . \%$. Keju di buat dari susu segar sebanyak 28 liter yang di pasteurisasi yaitu dilakukan pemanasan dengan suhu pasteurisasi High Temperature Long Time (HTLT yakni pada suhu tinggi $70^{\circ} \mathrm{C}$ selama 15 menit). Kemudian suhu diturunkan selama 30 menit sampai mencapai suhu $40^{\circ} \mathrm{C}$ ditambahkan enzim bromelin $3 \%$, dengan perlakuan variasi $\mathrm{pH}$ kedalam susu kemudian diinkubasi selama 35 menit, kemudian disaring mengunakan kain kasa untuk mendapatkan curd dan ditambahkan garam 1\%, lalu ditimbang. Kemudian dilakukan pengujian organoleptik.

Data yang diperoleh dianalisis dengan Anova, jika terdapat perbedaan pengaruh akan dilanjutkan dengan Uji Beda Nyata Terkecil (BNT) dengan menggunakan aplikasi perangkat lunak SPSS versi 16.0 (Subali,2010).

\section{Prosedur Penentuan Uji Organoleptik ( Watts, Ylimaki and Jeffrey, 1989).}

Uji organoleptik dengan metode Scoring test for intensity yang dilakukan pada keju cottage meliputi, rasa, aroma, warna, aftertaste, dan overall dengan panelis semi terlatih. Sampel organoleptic disiapkan secara acak dan ditempatkan dalam sebuah wadah piring dan diberi kode sampel. Setiap pindah sampel berikutnya didahului dengan air putih untuk menetralkan alat indera dalam rongga mulut. Prosedur pengujian untuk rasa, aroma, aftertaste, dan overall sesuai dengan tingkat kesukaan dan diisi dalam lembaran format uji.

\section{HASIL DAN PEMBAHASAN}

Data uji organoleptik keju cottage meliputi: rasa, aroma, warna, aftertaste, dan overall tertera pada tabel 1 .

\section{Uji Organoleptik Rasa}


Pengujian organoleptik sangat penting dilakukan karena merupakan salah satu faktor yang dapat digunakan untuk mengukur tingkat penerimaan dan kesukaan konsumen terhadap suatu produk. Metode yang digunakan adalah Scoring test for intensity yang dilakukan pada keju cottage meliputi rasa, aroma, warna, aftertaste dan overall. Pengujian organoleptik terhadap komponen rasa yang terdapat dalam suatu produk bahan pangan alami atau olahan merupakan salah satu parameter yang sangat menentukan penerimaan konsumen terhadap produk tersebut.

Pengujian organoleptik rasa dengan variasi $\mathrm{pH}$ memberikan perbedaan yang tidak nyata sehingga dapat disimpulkan bahwa terdapat perbedaan yang tidak signifikan rata-rata rasa antar perlakuan. Dapat terlihat dari rata-rata penilaian tentang rasa yang relatif sama antar perlakuan.

Cita rasa suatu bahan pangan adalah respon ganda dari bau dan rasa, apabila digabungkan dengan perasaan dari makanan didalam mulut, panelis dapat membedakan suatu makanan dengan jenis makanan lain. Perbedaan penilaian panelis terhadap rasa dapat diartikan sebagai penerimaan cita rasa yang dihasilkan oleh kombinasi bahan yang digunakan. Karakteristik rasa untuk skor 1: tidak ada rasa keju, skor 2: sedikit rasa keju, skor 3: agak banyak rasa keju, skor 4: banyak rasa keju, skor 5: banyak sekali rasa keju.

Berdasarkan hasil uji organoleptik yang dilakukan, rata-rata panelis memberikan penilaian dengan banyak rasa keju terhadap keju cottage yang dihasilkan. Penilaian panelis terhadap rasa nilai rataan $\mathrm{k} 1$ :3.40, K2: 3.60, K3:3.45 dan K4:3.60, rasa yang ditimbulkan oleh keju dengan variasi pH yang berbeda ternyata memberikan hasil yang tidak berbeda nyata. Hal ini menunjukkan bahwa penilaian panelis untuk rasa keju cottage dengan banyak rasa keju menunjukkan bahwa panelis menyukai rasa dari keju cottage yang dihasilkan.

Tabel 1, Rataan sifat organoleptik

\begin{tabular}{llccc}
\hline & \multicolumn{3}{c}{ Perlakuan } \\
\cline { 2 - 5 } Parameter & K1 & K2 & K3 & K4 \\
\hline Rasa & $3.40 \pm 0.503^{\mathrm{a}}$ & $3.60 \pm 0.503^{\mathrm{a}}$ & $3.45 \pm 0.510^{\mathrm{a}}$ & $3.60 \pm 0.503^{\mathrm{a}}$ \\
Aroma & $3.60 \pm 0.503^{\mathrm{a}}$ & $3.80 \pm 0.410^{\mathrm{a}}$ & $3.60 \pm 0.503^{\mathrm{a}}$ & $3.60 \pm 0.503^{\mathrm{a}}$ \\
Warna & $3.40 \pm 0.503^{\mathrm{a}}$ & $3.80 \pm 0.410^{\mathrm{b}}$ & $3.60 \pm 0.503^{\mathrm{ab}}$ & $3.80 \pm 0.410^{\mathrm{b}}$ \\
Aftertaste & $4.60 \pm 0.503^{\mathrm{a}}$ & $4.80 \pm 0.410^{\mathrm{a}}$ & $4.80 \pm 0.410^{\mathrm{a}}$ & $4.60 \pm 0.503^{\mathrm{a}}$ \\
Overall & $3.65 \pm 0.489^{\mathrm{a}}$ & $3.80 \pm 0.410^{\mathrm{a}}$ & $3.60 \pm 0.503^{\mathrm{a}}$ & $3.80 \pm 0.410^{\mathrm{a}}$ \\
\hline
\end{tabular}

Keterangan: Notasi yang berbeda menunjukkan perbedaan yang nyata $(\mathrm{P}<0.05)$

\section{Uji Organoleptik Aroma}

Aroma banyak menentukan kelezatan dari suatu bahan makanan. Walaupun suatu bahan pangan banyak mempunyai nilai gizi yang tinggi, tetapi ketika seorang mencium aroma tidak sedap maka orang tersebut akan menjauhi bahan pangan tersebut. Sebelum mencicipi bahan pangan tersebut sudah ada respon tidak suka karena ada aroma yang ditimbulkan. 
Berdasarkan tabel 1 dapat terlihat bahwa rata-rata aroma keju tertinggi pada perlakuan $\mathrm{K} 2$ sebesar 3.80, dan rata-rata aroma keju terendah pada perlakuan K1, R3, dan K4 yaitu sebesar 3.60. Karakteristik uji aroma keju untuk skor 1: tidak bau keju, skor 2: agak tidak bau keju, skor 3: Agak bau keju, skor 4: bau keju, skor 5: sangat bau keju. Penilaian panelis terhadap aroma nilai rataan K1:3.60, K2: 3.80, $\mathrm{K} 3: 3.60$, K4 3.80. Aroma yang ditimbulkan oleh variasi $\mathrm{pH}$ yang berbeda ternyata memberikan hasil yang tidak berbeda nyata. Hal ini menunjukkan bahwa panelis menyukai aroma bau keju cottage yang dihasilkan.

Berdasarkan hasil yang tercantum pada tabel 1 diperoleh nilai $\mathrm{F}$ hitung lebih kecil dari $\mathrm{F}$ tabel $(0.864<2.725)$, dan nilai signifikansi yang lebih besar dari $\alpha(0.464>0.050)$, sehingga dapat disimpulkan bahwa terdapat perbedaan yang tidak signifikan rata-rata aroma keju antar perlakuan. Dapat terlihat dari rata-rata penilaian tentang aroma keju yang relatif sama antar perlakuan. Selain itu, dalam proses pengolahan keju terjadi proses glikolisis dan proteolisis yang berperan dalam pembentukan aroma keju cottage. Hal ini sesuai dengan pendapat Gawad (2011) yang menyatakan bahwa aroma adalah bau yang ditimbulkan oleh rangsangan kimia yang tercium oleh syaraf-syaraf olfaktori yang berada dalam rongga hidung, aroma pada keju dihasilkan oleh kerja bakteri asam laktat yang berperan untuk menimbulkan aroma dan asam. Menurut Salles et al. (2002) dalam proses pengolahan keju secara umum terjadi 3 proses metabolisme yang penting yaitu glikolisis, proteolisis, dan lipolisis. Glikolisis adalah fermentasi laktosa oleh bakteri asam laktat yang digunakan untuk menghasilkan asam laktat, asam asetat, $\mathrm{CO}_{2}$, dan diasetil. Proteolisis adalah proses penguraian protein (kasein) menjadi peptida selanjutnya menjadi asam amino yang merupakan prekursor aroma sedangkan lipolisis adalah proses penguraian lemak menjadi asam lemak bebas dalam keju yang merupakan indikator pematangan keju dan berperan dalam pembentukan aroma keju.

\section{Uji Organoleptik Warna Keju}

Warna merupakan salah satu instrument sensori yang sangat menentukan penilaian panelis. Penentuan warna bergantung ada warna yang dimiliki oleh produk apakah terlihat menarik atau tidak. Hal ini sesuai dengan Winarno (2007), yang menyatakan bahwa salah satu faktor yang dipertimbangkan yaitu faktor warna yang lebih berpengaruh dan kadang-kadang sangat menentukan suatu bahan pangan yang dinilai dibandingkan enak atau bergizi.

Berdasarkan tabel 1, dapat terlihat bahwa rata-rata warna tertinggi pada perlakuan $\mathrm{K} 2$, K4 sebesar 3.80, dan rata-rata warna terendah pada perlakuan K1 yaitu sebesar 3.40. Karakteristik warna keju untuk skor 1: menyimpang, skor 2: putih terang, skor 3: putih, skor 4: putih kekuningan, skor 5: kuning. Penilaian panelis untuk warna nilai rataan K1:3.40, K2:3.80 ,K3:3.60, K4 3.80. 
Hasil analisis ragam menunjukkan bahwa terdapat pengaruh yang berbeda nyata $(\mathrm{p}<0.05)$ dilanjutkan dengan uji BNT yang dapat dilihat dengan notasi yang berbeda. Dari kolom notasi tersebut diperoleh hasil bahwa: Perlakuan K1 (a) berbeda signifikan dengan perlakuan K2 dan K4, tetapi perlakuan K1 tidak berbeda signifikan dengan perlakuan R3. Perlakuan R2 (b) berbeda signifikan dengan perlakuan K1, tetapi perlakuan K2 tidak berbeda signifikan dengan perlakuan K3, dan K4. Perlakuan K3 (ab) tidak berbeda signifikan dengan perlakuan K1, K2, dan K4. Perlakuan K4 (b) berbeda signifikan dengan perlakuan K1, tetapi perlakuan K4 tidak berbeda signifikan dengan perlakuan K2, dan K3.

Warna yang ditimbulkan oleh keju dengan variasi $\mathrm{pH}$ yang berbeda ternyata memberikan perbedaan yang nyata. Northcutt, (2009) menyatakan, warna keju adalah faktor penting karena konsumen mengasosiasikannya dengan kesegaran produk, yang kemudian mengambil keputusan untuk membeli atau tidak produk tersebut berdasarkan opini daya tarik mereka. Sejalan dengan itu, Pérez-Alvarez and Fernández-López (2012), mengemukakan, warna merupakan aspek utama yang mendefinisikan kualitas suatu produk pangan, dan mempengaruhi pilihan konsumen.

Menurut Fulya,(2006) warna putih dari susu diakibatkan oleh disperse yang merefleksikan sinar dari globula-globula lemak serta partikel koloid senyawa kasein dan kalsium fosfat.

\section{Uji Organoleptik Aftertaste}

Berdasarkan tabel 1, dapat terlihat bahwa rata-rata after taste tertinggi pada perlakuan $\mathrm{K} 2$ dan $\mathrm{K} 3$ sebesar 4.80, dan rata-rata after taste terendah pada perlakuan $\mathrm{K} 1$ dan $\mathrm{K} 4$ yaitu sebesar 4.60. karakteristik aftertaste keju skor 1: menyimpang, skor 2: sangat pahit, skor 3: rasa pahit, skor 4: rasa pahit sedikit, skor 5: tidak ada rasa pahit.

Hasil analisis ragam menunjukkan terdapat perbedaan yang tidak signifikan rata-rata after taste antar perlakuan. Dapat terlihat dari rata-rata penilaian tentang after taste yang relatif sama antar perlakuan. Rata-rata penilaian panelis terhadap aftertaste tidak berbeda nyata. Aftertaste yang dirasakan oleh panelis umumnya adalah tidak ada rasa pahit yang tertinggal.

\section{Uji Organoleptik Overall}

Berdasarkan tabel 1, dapat terlihat bahwa rata-rata overall tertinggi pada perlakuan K2 dan K4 sebesar 3.80, dan rata-rata overall terendah pada perlakuan K3 yaitu sebesar 3.60. Karakteristik overall keju skor 1: sangat tidak enak, skor 2: tidak enak, skor 3: netral, skor 4: enak, skor 5: sangat enak. Secara keseluruhan keju cottage dengan perlakuan-perlakuan tersebut panelis merasa enak.

Hasil analisis ragam menunjukkan bahwa terdapat perbedaan yang tidak signifikan $(\mathrm{P}>0.05)$ ratarata overall antar perlakuan. Dapat terlihat dari rata-rata penilaian tentang keseluruhan yang relatif sama 
Jurnal Sains Peternakan

Vol 7 No 1, Juni 2019, 54-61

ISSN 2579-4450

antar perlakuan. Kesatuan interaksi antara sensasi rasa, aroma, warna aftertaste akan membentuk keseluruhan citarasa, dan aftertaste akan membentuk keseluruhan citarasa produk pangan yang dinilai overall.

Kesatuan interaksi antara sensasi rasa, aroma, warna aftertaste akan membentuk keseluruhan citarasa, dan aftertaste akan membentuk keseluruhan citarasa produk pangan yang dinilai overall.

\section{KESIMPULAN}

Dari hasil penelitian ini disimpulkan bahwa sifat organoleptik secara overall dapat diterima oleh konsumen.

\section{DAFTAR PUSTAKA}

AOAC, 2005. Analysis of Official Analytical Chemestry Methods. 18 th.Ed Washington DC.

Chandan, R.C., A. Kilara, N. P. Shah. 2016. Dairy Processing and QualityAssurance. Wiley Blackwell. United Kingdom

Chang, R. 2005. Kimia Dasar: Konsep-konsep Inti. Vol.2. Penerbit Erlangga. Jakarta

Fulya,K.(2006). Effect of Traditional Starter Cultures on quality of Cheese middle East Technical University.

Kapoor R, Metzger L.E. (2008) Process cheese; Scientific and Technological Aspect: A Review. Comprehensive Reviews in Food Safety 7: 194-214.

Jaya, F. dan D. Hadikusuma. 2009. Pengaruh Substitusi Susu Sapi Dengan Susu Kedelai Serta Besarnya Konsentrasi Penambahan Ekstrak Nenas (Ananas comosus) Terhadap Kualitas Fisik Dan Kimia Keju Cottage. JITEK 4(1): 46-54

McMahon Dj, Paulson B, Oberg C.J (2005). Influense of Calcium, pH and Moiusture on Protein Matrix Structure and Functionality in Direct-acidifield Nonfat Mozzarella Cheese. Journal of Dairy Science 88:3754.

Nisa, T.K. 2013. Pengaruh Substitusi Nangka Muda (Artocarpus heterophyllus Lmk) Terhadap Kualitas Organoleptik Nugget Ayam. Food Science and Culinary Education Journal. 2 (1) : 63-71

Northcutt, Julie K. 2009. Factors Affecting Poultry Meat Quality The University of Georgia Cooperative Extension Service The University's Bull. 1157.

Pérez-Alvarez, J.Á and J.Fernández-López. 2012. Chemical and Biochemical Aspects of Color in Muscle Foods. In: Handbook of Meat, Poultry and Seafood Quality, $2^{\text {nd }}$ Ed. Edited by Leo M. L. Nollet. Pub. by John Wiley \& Sons, Inc.

Salles, C. N, Sommerer, C. Septier S. Issanchou, C. Chabanet, A. Garem, dan J.-L. Le Quere. 2002. Goat Cheese Flavor : Sensory Evaluation of Branched-Chain Fatty Acids and Small Peptides. 
Jurnal Sains Peternakan

Vol 7 No 1, Juni 2019, 54-61

ISSN 2579-4450

Journal of Fodd Science, V67 (2) : 835-841. http://www.scribd.com/doc/50709339/38/P-12. Diakses [31 Januari 2012].

Subali. B. 2010. Analisis Statistika Menggunakan program SPSS Aplikasinya dalam Rancangan Percobaan. Jurusan Pendidikan Biologi, Fakultas MIPA. Universitas Negeri Yogyakarta. Yogjakarta.

Sumardjo, D. 2006. Pengantar Kimia: Buku Panduan Kuliah Mahasiswa KEdokteran dan Program Strata I Fakultas Bioeksakta. Penerbit Buku Kedokteran EGC. Jakarta.

Watts, B.M., G.L. Ytimaki., L.E. Jeffery, and L.G. Elias. 2003. Dasar-dasar Metode Sensori Untuk Evaluasi Bahan Pangan. Diterjemahakan Oleh Purwadi. Fakultas Peternakan. Universitas Brawijaya Malang. 